\title{
Molecular Phylogeny of Balsams (Genus Impatiens) Based on ITS Regions of Nuclear Ribosomal DNA Implies Two Colonization Events in South India
}

\author{
P. P. Shajitha ${ }^{1}$, N. R. Dhanesh ${ }^{1}$, P. J. Ebin ${ }^{2}$, Laly Joseph ${ }^{3}$, Aneesha Devassy ${ }^{1}$, Reshma John ${ }^{1}$, Jomy Augustine ${ }^{4}$, Linu \\ Mathew $^{1 *}$ \\ ${ }^{1}$ School of Biosciences, Mahatma Gandhi University, Kottayam, Kerala, India. \\ ${ }^{2}$ Department of Botany, Sacred Heart College, Cochi, Ernakulam, Kerala, India. \\ ${ }^{3}$ Gurukula Botanical Sanctuary, Wayanad, Kerala, India. \\ ${ }^{4}$ Department of Botany, St. Thomas College, Palai, Kottayam, Kerala, India.
}

\section{ARTICLE INFO}

Article history:

Received on: 07/06/2016

Revised on: 28/07/2016

Accepted on: 11/08/2016

Available online: 05/11/2016

Key words:

Impatiens species, Molecular

Phylogeny, Internal

Transcribed Spacer,

Maximum Parsimony,

Bayesian Inference.

\begin{abstract}
The present investigation is the first attempt of its kind to analyze the phylogenetic association of Impatiens species of South India by placing them in the global Internal Transcribed Spacer (ITS) phylogeny of Impatiens. Representative samples from all the seven sections of genus Impatiens reported from South India were collected. Total genomic DNA was extracted from fresh plant leaf and Polymerise Chain Reaction (PCR) was carried out using ITS specific forward and reverse primers. Forty seven sequences from representatives of seven sections of Impatiens species from South India and 45 Impatiens sequences from other centers of Impatiens diversity were obtained from GenBank and used to reconstruct the evolutionary relationships within the genus Impatiens. Maximum Parsimony (MP) analysis was conducted by using PAUP*v.4.0b10. Bayesian Inference (BI) analysis was carried out in MrBayes v.3.2.2. Molecular phylogeny of South Indian Impatiens spp. based on ITS sequences showed the same association as that of morphological taxonomy. This study including all representative extant sections of South India, indicates that South India was colonized from Southeast Asia by two independent dispersal events i.e., once by ancestral species of sections Scapigerae, Epiphyticae, Tomentosae, Sub-Umbellatae and Racemosae and another time by ancestral species of sections Microsepalae and Annuae.
\end{abstract}

\section{INTRODUCTION}

The family Balsaminaceae comprises only two genera, Impatiens and Hydrocera. The genus Impatiens is a large genus consisting of more than 1000 species and is mainly distributed in mountain areas of old world tropics and subtropics [1]. The genus Hydrocera has a single species, Hydrocera triflora, a semiaquatic herb native to the Indo-Malaysian countries [2].Other generic names, for example, Petalonema, Semeiocardium and Impatientella are confirmed to be synonyms of the genus Impatiens [3, 4]. The species of Impatiens are significant as ornamentals, medicinals and experimental plant materials in botanical research [5].

* Corresponding Author

Linu Mathew, School of Biosciences, Mahatma Gandhi University,

Kottayam, Kerala, India, P.O. Code 686 560, Tel +919447505690,

Fax:91-481-2731002,E-mail: linumathew@mgu.ac.in
Five biodiversity hotspots for Impatiens have been identified that is Southeast Asia, Southern India and Sri Lanka, Tropical Africa, Madagascar and the Eastern Himalayas. Several novel species are recognized in these regions every year $[6,7,8]$. A minute number of Impatiens species are represented in the temperate areas in Europe, Northern China and North America [1] with no indigenous species in South America and Australia [2]. High proportions of endemism are related with these hotspots, for example, nearly $91 \%$ of the Southern Indian species and almost all the native species of Madagascar are endemic [4]. In India, the concentration of Impatiens species is amazingly local and occurs in two well-defined regions, viz., the Himalaya in the North and the Western Ghats mountain ranges in the South. The genus Impatiens contains more than 210 species in India, over half of which occurs in the Western Ghats and at least 103 species of Impatiens are endemic to the Western Ghats [5]. Several hypotheses related to the origin of Impatiens spp were proposed based on species diversity, karyological data, morpholological similarity etc. [9, 10]. 
Bhaskar [11] suggested that South India contains majority of the phylogenetically old species and Western Ghats is the places of origin of Impatiens considering the concentration of diploids, primitive radial pollen grains and shrubby habit. Phylogenies of Impatiens species based on ITS sequences of Yuan et al. [2] revealed that extant Impatiens species are of Southeast Asian origin, from where it dispersed to boreal Eurasia and North America, to central Asia and Eastern Europe via the Himalayas, and to India and Africa.

Janssens et al. [1], atpB-rbcL spacer sequences phylogenetics suggested that Impatiens originated in South China from which it colonized the nearby regions and afterwards dispersed to North America, India, Africa, the Southeast Asian peninsula, and the Himalayan area. Based on morphological characters combined with sequence data from three genetic regions, including nuclear ribosomal ITS, plastid $a t p B-r b c L$ and trnL-F, Yu et al. [12] presented a new classification of Impatiens, in which Impatiens is divided into two subgenera, subgenus Clavicarpa and subgenus Impatiens.

The subgenus Impatiens is further subdivided into seven sections. In the published data of phylogeny and biogeography of Balsaminaceae inferred from ITS sequences of Yuan et al. [2] and phylogenetics of Balsaminaceae using chloroplast atpB-rbcL spacer sequences of Janssens et al. [1] contained only a few samples of Impatiens species from South India. Hence this can be considered as the first work on the molecular phylogeny of Impatiens species of South India including representative species from all seven sections of the genus Impatiens from South India.

\section{MATERIALS AND METHODS}

\subsection{Taxon Sampling}

Representative samples from the seven sections of Impatiens species were collected from different locations of Western Ghats. The plants were identified in the field with help of the taxonomic monograph on Impatiens L. (Balsaminaceae) of Western Ghats, South India [5].

The specimens were collected and brought to the lab for further molecular analysis. The plants were authenticated by Dr. Jomy Agustine (Taxonomist, Department of Botany, St. Thomas College, Palai, Kottayam, Kerala, India). Voucher specimens were deposited in the Herbarium of St. Thomas College (Palai, Kerala, India). The details of sample collection are summarized in Table 1.

\subsection{Molecular Protocols}

Total genomic DNA was extracted using Gen Elute Plant Genomic DNA Miniprep Kit (Sigma Aldrich, St. Louis, USA). For PCR amplification, OrionX h-Taq PCR Smart Mix (Origin, India) was used.

The primers used for the amplification of the ITS gene were ITS 4- 5'-GGAAGTAGAAGTCGTAACAAGG-3' and ITS 5- 5'-TCCTCCGCTTATTGATATGC-3' [13]. The temperature profile consisted of 2 min initial denaturation at $95^{\circ} \mathrm{C}$ followed by 35 cycles of $30 \mathrm{~s}$ denaturation at $95^{\circ} \mathrm{C}, 30 \mathrm{~s}$ primer annealing at $50.9^{\circ} \mathrm{C}, 1 \mathrm{~min}$ extension at $72^{\circ} \mathrm{C}$ and a final extension of $8 \mathrm{~min}$ at $72^{\circ} \mathrm{C}$

Amplification reactions were carried out in an Agilent Sure Cycler 8800 (Agilent Technologies, USA). PCR products were sequenced (Scigenome Labs Pvt. Ltd., Cochin, Kerala, India) in AB1 Cycle sequencer.

\subsection{Data Matrices and alignment}

ITS sequences were initially aligned using the CLUSTALW [14] algorithm in BioEdit V. 7.0.5.2 [15] applying the default parameters for gap opening and gap extension. Non- informative or ambiguous gaps were not coded. Only the indel coded data matrices were used for phylogenetic analyses.

\subsection{Phylogenetic analysis}

All sequences generated in this study were subjected to a search in BLAST (NCBI) against the GenBank nucleotide database and submitted to GenBank (Table 1). H. triflora was kept as out group (GenBank Accession No. AY348853). Sequences of Impatiens species from five diversity hotspots were collected from GenBank (Table 2). The sequences were multiple aligned using the CLUSTALW [14] program using BioEdit 7.0.5.2 [15].

Maximum parsimony (MP) analyses were conducted using PAUP*v.4.0b10 [16]. Heuristic searches were performed on a gap-coded data set with 10 replicates of the random addition option and one tree held at each step during stepwise addition. Branch-swapping algorithm was tree-bisection-reconnection (TBR) and steepest descent option off. Initial 'MaxTrees' setting was 100 and 'MulTrees' option was in effect. Characters were equally weighted and character states were specified to be unordered. Supports for various nodes were determined through 1000 bootstrap replications.

The Akaike information criterion (AIC) implemented in the program j-modelTest version 2.1.5 [17] was used to choose substitution models that best fit the dataset through hierarchical likelihood ratio tests and to estimate the transition-transversion rate ratio, gamma shape parameters and base frequencies under the best supported model.

Bayesian Inference (BI) analyses were carried out in MrBayes v.3.2.2 [18] in two independent runs, each with one heated chain and one cold chain and each run consisted of Markov Chain Monte Carlo (MCMC) methods to estimate the posterior distribution of model parameters for 1 lakh generations. Convergence occurred when standard deviation (SD) of split frequencies fell below 0.05 ; the first $25 \%$ of MCMC generations were discarded as burn-in. Posterior probability values were used to estimate branch support. Trees were visualized by Fig Tree, Tree Figure drawing tool version 1.4.2 [19]. 
Table 1: Sampled species used in this study with Location, Voucher No. and GenBank accession No.

\begin{tabular}{|c|c|c|c|c|}
\hline SI. No. & Species name with Section & Location $^{*}$ & Voucher No. of sample deposited & GenBank Accession Number \\
\hline & Section: Scapigerae & & & \\
\hline 1 & I. acaulis & Agasthyamala Biosphere Reserve & S.P.P.4862 & KR011120 \\
\hline 2 & I. levingei & Eravikulam National Park & S.P.P.4854 & KT225490 \\
\hline 3 & I. modesta & Eravikulam National Park & S.P.P. 4857 & KT225493 \\
\hline 4 & I. pandata & Eravikulam National Park & S.P.P.4856 & KT225494 \\
\hline \multirow[t]{2}{*}{5} & I. scapiflora & Vagamon & S.P.P.4502 & KJ685214 \\
\hline & Section: Epiphyticae & & & \\
\hline 6 & I. jerdoniae & Wayanad & S.P.P.4525 & KT225492 \\
\hline \multirow[t]{2}{*}{7} & I. violacea & Wayanad & S.P.P.4858 & KT225495 \\
\hline & Section: Anпиае & & & \\
\hline 8 & I. chinensis & Munnar & S.P.P.4545 & KF804101 \\
\hline 9 & I. dalzellii & Eravikulam National Park & S.P.P. 4852 & KT225491 \\
\hline 10 & I.debilis & Wayanad & S.P.P.4544 & KF804102 \\
\hline 11 & I. gardneriana & Wayanad & S.P.P. 4520 & KF719156 \\
\hline 12 & I. herbicola & Neryamangalam & S.P.P.4505 & KF719158 \\
\hline 13 & I. ligulata & Wayanad & S.P.P. 4530 & KF719159 \\
\hline 14 & I. lucida & Munnar & S.P.P.4519 & KF719160 \\
\hline 15 & I. minor & Neryamangalam & S.P.P.4504 & KF719162 \\
\hline 16 & I. oppositifolia & Eravikulam National Park & S.P.P.4855 & KT254232 \\
\hline 17 & I. raziana & Eravikulam National Park & S.P.P.4851 & KT254235 \\
\hline 18 & I. rufescens & Wayanad & S.P.P. 4542 & KT254236 \\
\hline \multirow[t]{2}{*}{19} & I. tomentosa & Agasthyamala Biospher Reserve & S.P.P.4861 & KT254238 \\
\hline & Section: Microcepalae & & & \\
\hline 20 & I. bababudenensis & Anamudi Hills & S.P.P.4548 & KT254226 \\
\hline 21 & I. balsamina & Munnar & S.P.P. 4517 & KF804100 \\
\hline 22 & I. cuspidata & Munnar & S.P.P.4509 & KF719153 \\
\hline 23 & I. dasysperma & Neryamangalam & S.P.P.4506 & KJ685213 \\
\hline 24 & I. flaccida & Vagamon & S.P.P.4516 & KT254228 \\
\hline 25 & I. floribunda & Wayanad & S.P.P. 4521 & KF719155 \\
\hline 26 & I. latifolia & Eravikulam National Park & S.P.P.4549 & KT254231 \\
\hline 27 & I. mysorensis & Wayanad & S.P.P. 4534 & KF719164 \\
\hline 28 & I. pulcherrima & Eravikulam National Park & S.P.P.4853 & KT254234 \\
\hline 29 & I. scabriuscula & Wayanad & S.P.P.4531 & KF719168 \\
\hline \multirow[t]{2}{*}{30} & I. walleriana & Munnar & S.P.P. 4518 & KF804104 \\
\hline & Section: Tomentosae & & & \\
\hline 31 & I. henslowiana & Munnar & S.P.P.4508 & KT254230 \\
\hline 32 & I. johnii & Wayanad & S.P.P. 4543 & KF804103 \\
\hline \multirow[t]{2}{*}{33} & I. neo-munronii & Wayanad & S.P.P. 4523 & KF719165 \\
\hline & Section: Sub-Umbellatae & & & \\
\hline 34 & I. anaimudica & Anamudi Hills & S.P.P.4550 & KT254225 \\
\hline 35 & I. cordata & Munnar & S.P.P. 4515 & KT254227 \\
\hline 36 & I. disotis & Wayanad & S.P.P. 4528 & KF719154 \\
\hline 37 & I. goughii & Neryamangalam & S.P.P. 4510 & KF719157 \\
\hline 38 & I. grandis & Wayanad & S.P.P. 4524 & KT254229 \\
\hline 39 & I. travancorica & Eravikulam National Park & S.P.P. 4547 & KT254239 \\
\hline 40 & I. umbellata & Agasthyamala Biospher Reserve & S.P.P.4859 & KT254240 \\
\hline 41 & I. uncinata & Wayanad & S.P.P.4529 & KT254241 \\
\hline 42 & I. viscida & Munnar & S.P.P.4533 & KF719166 \\
\hline \multirow[t]{2}{*}{43} & I. viscosa & Munnar & S.P.P. 4538 & KF697232 \\
\hline & Section: Racemosae & & & \\
\hline 44 & I. maculata & Devikulam & S.P.P.4507 & KF719161 \\
\hline 45 & I. phoenicea & Wayanad & S.P.P.4527 & KT254233 \\
\hline 46 & I. tangachee & Eravikulam National Park & S.P.P. 4860 & KT254237 \\
\hline 47 & I. wightiana & Wayanad & S.P.P. 4522 & KF719167 \\
\hline
\end{tabular}

*All locations in Kerala, India. 
Table 2: Details of sequences obtained from GenBank.

\begin{tabular}{|c|c|c|}
\hline SI. No. & Place of origin and Species name & Genbank Accession Number \\
\hline & Sri Lanka & \\
\hline \multirow[t]{2}{*}{1} & H. triflora (out group) & AY348853 \\
\hline & East and Southeast Asia & \\
\hline 2 & I. aureliana & AY348747 \\
\hline 3 & I. bicornuta & AY348754 \\
\hline 4 & I. clavigera & HQ718766 \\
\hline 5 & I. monticola & AY348810 \\
\hline 6 & I. napoensis & AY348811 \\
\hline 7 & I. omeiana & КС905505 \\
\hline 8 & I. platypetala & AY348819 \\
\hline 9 & I. stenosepala & AY348835 \\
\hline 10 & I. trichosepala & AY348843 \\
\hline \multirow[t]{2}{*}{11} & I. xanthina & AY348850 \\
\hline & Africa & \\
\hline 12 & I. bequaerti & AY348753 \\
\hline 13 & I. bombycina & AY348755 \\
\hline 14 & I. burtonii & AY348757 \\
\hline 15 & I. congolensis & AY348766 \\
\hline 16 & I. columbaria & AY348764 \\
\hline 17 & I. hoehnelii & AY348792 \\
\hline 18 & I. keilii & AY348798 \\
\hline 19 & I. kilimanjari & AY348800 \\
\hline 20 & I. niamniamensis & AY348812 \\
\hline \multirow[t]{2}{*}{21} & I. stuhlmannii & AY348836 \\
\hline & Madagascar & \\
\hline 22 & I. auricoma & AY348748 \\
\hline 23 & I. baroni & AY348751 \\
\hline 24 & I. fuchsioides & AY348785 \\
\hline 25 & I. furcata & AY348786 \\
\hline 26 & I. gibbosa & AY348787 \\
\hline 27 & I. inaperta & AY348797 \\
\hline 28 & I. percrenata & AY348817 \\
\hline 29 & I. subabortiva & AY348837 \\
\hline 30 & I. tuberosa & AY348844 \\
\hline \multirow[t]{2}{*}{31} & I. vilersi & AY348848 \\
\hline & South India and Sri Lanka & \\
\hline 32 & I. campanulata & AY348758 \\
\hline 33 & I. cordata ${ }^{1}$ & AY348768 \\
\hline 34 & I. cuspidata ${ }^{1}$ & AY348769 \\
\hline 35 & I. henslowiana ${ }^{1}$ & AY348790 \\
\hline 36 & I. latifolia ${ }^{l}$ & AY348801 \\
\hline 37 & I. leschenaultii & AY348803 \\
\hline 38 & I. levingei ${ }^{l}$ & AY348804 \\
\hline \multirow[t]{2}{*}{39} & I. repens & КС905524 \\
\hline & The Himalayas & \\
\hline 40 & I. amphorata & AY348740 \\
\hline \multirow[t]{2}{*}{41} & I. glandulifera & AY348788 \\
\hline & Central Asia and Europe & \\
\hline 42 & I. brachycentra & AY348756 \\
\hline \multirow{2}{*}{43} & I. parviflora & AY348816 \\
\hline & Boreal Eurasia and North America & \\
\hline 44 & I. nolitangere & AY348813 \\
\hline 45 & I. capensis & AY348759 \\
\hline
\end{tabular}

\section{RESULTS}

ITS gene sequences of forty-five Impatiens species, including all the five biodiversity hotspots, were obtained from the NCBI database. A total of forty-seven sequences of South Indian Impatiens were generated in the present study including all the seven sections of the genus Impatiens. H. triflora was selected as outgroup in all the analyses. MP analysis of the ITS data matrix included 92 taxa and 503 characters. Out of the 503 characters, 198 were constant and 86 variable characters, which were parsimony-uninformative. The parsimony-informative characters were 219. The strict consensus of the optimal tree kept by heuristic searches and the bootstrap clade support (when greater than 50\%) was showed (Figure 1). The MP strict consensus tree was moderately resolved. The resolved lineages of Impatiens were grouped into five clades. Southeast Asian Impatiens species viz., I. clavigera and I. omeiana formed a basal clade 1 with high bootstrap support (BSS) of $100 \%$. I. stenosepala (Southeast Asian origin) was resolved as a highly supported clade 2 with strong BSS of $99.5 \%$. The North American species, I. capensis showed close affinity with the boreal temperate Eurasian species, I. noli-tangere (100\%) forming clade 3 with weak BSS of $57.2 \%$. 


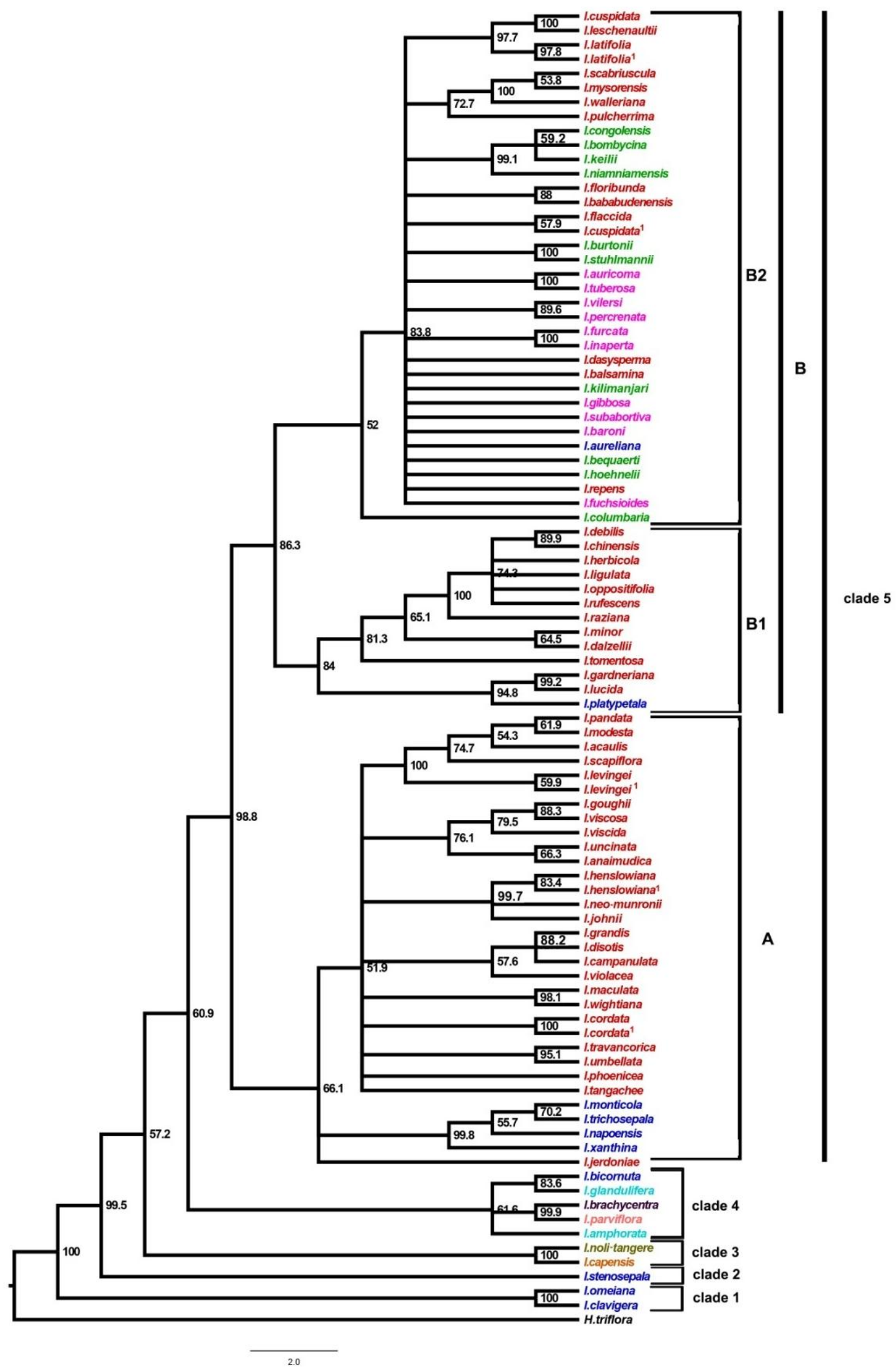

Fig. 1: Consensus tree from the Maximum Parsimony analysis based on nuclear ITS gene. The numbers by the nodes indicate maximum parsimony bootstrap support values greater than $50 \%$. 


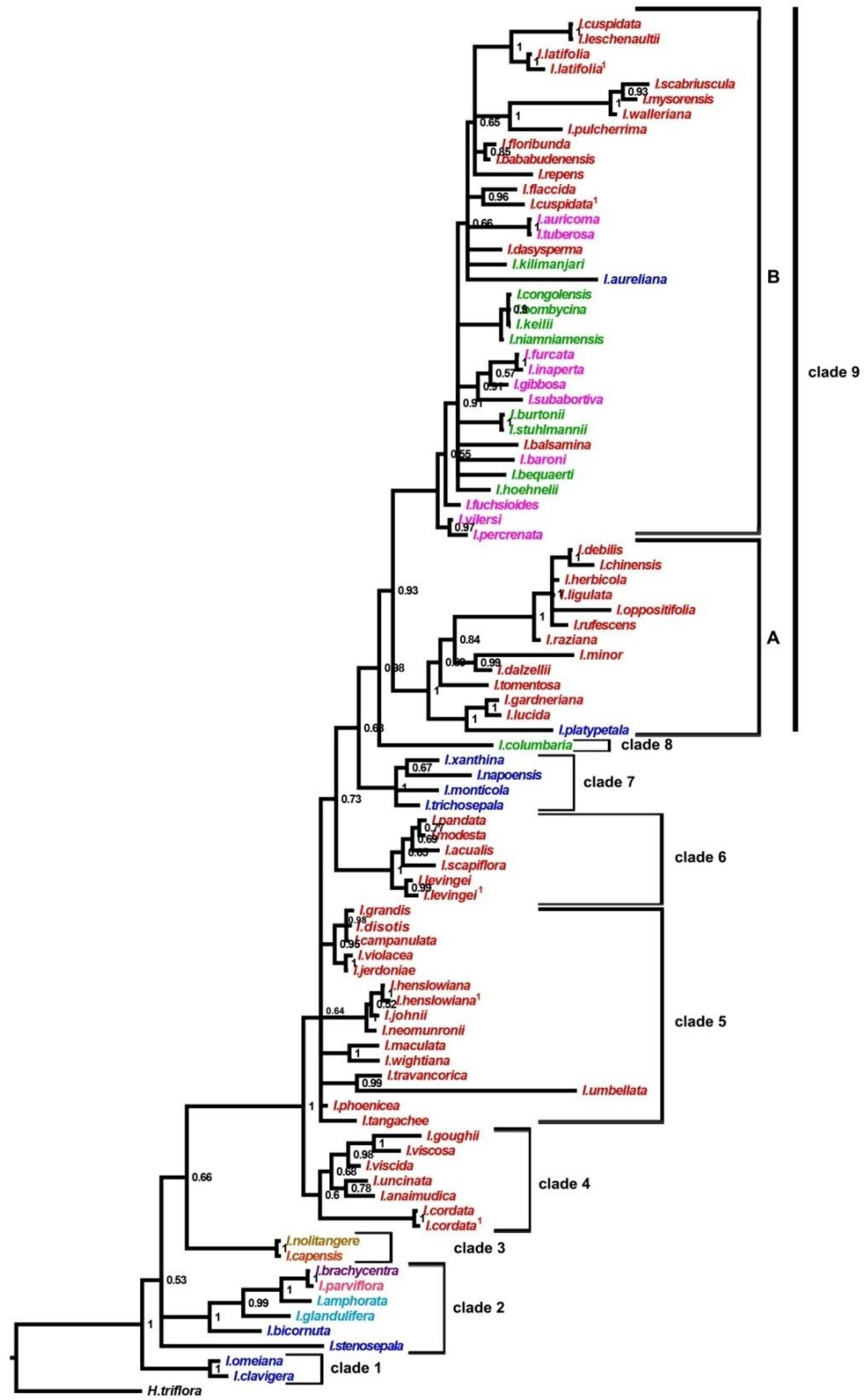

Fig. 2: Bayesian consensus phylogram based on nuclear ITS gene. The numbers by the nodes indicate bayesian posterior probabilities greater than 0.5 . 
The Eastern European species, I. parviflora and the central Asian species, I. brachycentra were grouped together. The Southeast Asian species, I. bicornuta and the Himalayan species $I$. glandulifera were also grouped together. These two groups showed affinity to the Himalayan species I. amphorata and formed clade 4 with moderate BSS of $60.9 \%$. Clade 5 was a large clade with high BSS of $98.8 \%$ and was divided into two sub clades i.e., A and B. The sub clade A showed a grouping of Southeast Asian species (I. xanthina, I. napoensis, I. trichosepala and I. monticola) and the South Indian species of sections Epiphyticae (I. jerdoniae and I. violacea), Sub-Umbellatae (I. umbellata, I. travancorica, I. cordata, I. disotis, I. grandis, I. anaimudica, I. uncinata, I. viscida, I. viscosa and I. goughii), Scapigerae (I. levingei, I. scapiflora, I. acaulis, I. modesta and I. pandata), Racemosae (I. tangachee, I. phoenicea, I. wightiana and I. maculata) and Tomentosae (I. johnii, I. neo-munronii and I. henslowiana) with BSS of 66.1.\%. This sub clade contained sequences of South Indian species from NCBI, GenBank namely, I. cordata ${ }^{1}$, I. campanulata, I. henslowiana ${ }^{1}$ and I. levingei ${ }^{l}$. The sub clade B was divided into sub clade B1 and B2 with BSS of $86.3 \%$. The sub clade B1 (BSS $84 \%$ ) contained the South Indian species of section Annuae (I. lucida, I. gardneriana, I. tomentosa, I. dalzellii, I. minor, I. raziana, I. rufescens, I. oppositifolia, I. ligulata, I. herbicola, I. chinensis and I. debilis) and only one South east Asian species I. platypetala. The sub clade B2 comprised of all the selected African, Madagascan species and also South Indian (section Microsepalae) species with only one Southeast Asian species (I. aureliana) with weak BSS of $52 \%$. This sub clade contained African species like I. columbaria, I. hoehnelii, I. bequaerti, I. kilimanjari, I. stuhlmannii, I. burtonii, I. niamniamensis, I. keilii, I. bombycina and I. congolensis. The Madagascan species were $I$. fuchsioides, I. baroni, I. subabortiva, I. gibbosa, I. inaperta, I. furcata, I. percrenata, I. vilersi, I. tuberosa and I. auricoma. This clade also included South Indian species from NCBI like I. repens I. cuspidata $^{1}$, I. latifolia ${ }^{1}$ and I. leschenaultii. The species of section Microsepalae found in this clade were I. balsamina, I. dasysperma, I. flaccida, I. bababudenensis, I. floribunda, I. pulcherrima, I. walleriana, I. mysorensis, I. scabriuscula, I. latifolia and I. cuspidata.

A general time reversible model of evolution with invariant sites and a gamma distribution $(\mathrm{GTR}+\mathrm{I}+\mathrm{G})$ was selected using jModeltest 2.1.5 [17]. This model was used for the Bayesian Inference (BI) analysis. The BI tree had well-resolved topology and the overall relationships are depicted in almost the same way as in the MP analysis (Figure 2). The resolved lineages of Impatiens species were grouped into nine clades. Southeast Asian Impatiens species (I. clavigera and I. omeiana) formed clade 1 with strong BPP of 1.00. The clade 2 included the Southeast Asian species (I. stenosepala and I. bicornuta), the central Asian species (I. brachycentra), the Eastern European species (I. parviflora), and the Himalayan species (I. amphorata and I. glandulifera) with weak BPP of 0.53 . Clade 3 is grouped with the boreal temperate Eurasian species (I. noli-tangere) and the North American species (I. capensis) with moderate BPP of 0.66. Species of section Sub-
Umbellatae (I. cordata, I. anaimudica, I. uncinata, I. viscida, I. viscosa and I. goughii) formed clade 4 with strong BPP of 1.00. Clade 5 included species of sections Racemosae (I. tangachee, I. phoenicea, I. wightiana and I. maculata), Sub-Umbellatae (I. umbellata, I. travancorica, I. disotis and I. grandis), Tomentosae (I. neo-munronii, I. johnii and I. henslowiana) and Epiphyticae (I. jerdoniae and I. violaceae). In this clade, I. jerdoniae and $I$. violacea of section Epiphyticae grouped together with high BPP value 1.00. The clade 6 comprised only species of section Scapigerae (I. levingei, I. scapiflora, I. acaulis, I. modesta and I. pandata) with BPP 0.73. Clade 7 included only the Southeast Asian species (I. trichosepala, I. monticola, I. napoensis and I. xanthina) with BPP of 0.68. African species (I. columbaria) formed clade 8 with BPP of 0.98. Clade 9 (BPP 0.93) was divided into sub clade A and sub clade B. The sub clade A contained species of section Annuae and only one Southeast Asian species (I. platypetala) with strong BPP value 1.00 as same as in MP (sub clade B1) analysis. The sub clade B included African, Madagascan and the South Indian species (section Microsepalae) with strong BPP value 1.00 as same as in MP (sub clade B2) analysis.

\section{DISCUSSION}

\subsection{Biogeographic Implications of the ITS Phylogenies}

Balsaminaceae showed an interesting distributional pattern, with five biodiversity hotspots located in Africa, Madagascar, South India and Sri Lanka, the Himalayas and Southeast Asia [2]. Based on species diversity and karyological data, Jones and Smith [9] suggested that Impatiens originated in the Himalayan region and dispersed to other areas. Grey-Wilson [10] developed a hypothesis suggesting that Balsaminaceae originated in Western Gondwana and spread to Southeast Asia through Madagascar and India. From Southeast Asia and the adjacent Sino-Himalayan area, Impatiens diversified secondarily into two lineages: one lineage radiating to the temperate Eurasian areas and North America, and the other radiating to tropical and subtropical areas of Southeast Asian islands. Grey-Wilson [10] rejected the possibility of an overland migration between Africa and India.

Phylogenies of Impatiens species based on ITS sequences of Yuan et al. [2] revealed that extant Impatiens species are of Southeast Asian origin, from where it dispersed to boreal Eurasia and North America, to central Asia and Eastern Europe, via the Himalayas, and to India and Africa. Janssens et al. [2] $a t p B-r b c L$ spacer sequences based phylogeny suggested that Impatiens originated in South China from which it colonized the nearby regions and afterwards dispersed to North America, Africa, India, the Southeast Asian peninsula and the Himalayan area. Maximum-likelihood based ancestral area reconstruction of Janssens et al. [20] illustrated that the vast majority of the current diversification of Impatiens has originated in Asia. He also suggested that Southwest China was clearly reconstructed as the ancestral area for the earliest-diverging lineages.

Phylogenetic analyses of nuclear ITS data provides wellsupported trees that give a good hypothesis of evolutionary 
relationships in the genus Impatiens. Biogeographic analysis onto the ITS phylogenies revealed that Southeast Asia as the ancestral area of extant Impatiens species. All phylogenies clearly illustrate the Southeast Asian origin of the genus Impatiens. Yuan et al. [2] (based on ITS phylogeny) suggested that North American species I. capensis and boreal Eurasian species I. noli-tangere dispersed from Southeast Asia. In this study, these two species grouped together with strong bootstrap support (100\%). Yuan et al. [2] also suggested that the central Asian species I. brachycentra and European species I. parviflora may have been dispersed from Southeast Asia via the Himalayas. In this study, these species assembled with high support value and showed relationship with Himalayan species. These results are in confirmation with the findings of Yuan et al. [2]. Janssens et al. [1] suggested that only one speciation event from Southwest China accounts for the diversity of Impatiens in North America. ITS phylogeny of Yuan et al. [2] also suggested that Africa was colonized at least twice from Southeast Asia and Madagascan Impatiens showed clearly an African origin. Janssens et al. [1] based on $a t p B-r b c L$ phylogeny suggested that Madagascan species originated from an African ancestor. Studies of Janssens et al. [20] clearly illustrated that African continent was colonized from Southwest china in three independent dispersal events and Madagascan species was derived from a single colonization event. In this study, all the Madagascan and the African species occurred into the same sub clade. Due to insufficient sampling and less resolved clades, it is not possible to conclude the colonization events of African and Madagascan species from this study.

ITS phylogeny of Yuan et al. [2] contained only nine species from India and Sri Lanka. Of which some species ( $I$. campanulata, I. hookeriana, I. cordata, I. henslowiana and I. levingei) showed Southeast Asian connection and others ( $I$. cuspidata, I. parasitica, I. latifolia and I. leschenaultii) showed African connections. From this results Yuan et al. [2] concluded that South India and Sri Lanka had two origins and not commended the colonization events of this region. But Janssens et al. [1] atpB-rbcL based phylogeny confirmed that South India was colonized at least twice, once by an East Asian ancestor, another time by an ancestor with African affinities. Biogeographic reconstructions of Janssens et al. [20] revealed that Impatiens dispersed into South India via two independent colonization events from Southwest China.

In this study, all the analyses show that South Indian species belonged to recent lineages of Impatiens. South Indian species contained clade 5 (in MP) was obviously separated into two sub clades A and B. Of the total sampled South Indian species, some species grouped with Southeast Asian species (sub clade A in MP analysis) and some species grouped with African species (sub clade B in MP and BI analyses). The present study contained species, I. cordata, I. henslowiana and I. levingei showing Southeast Asian connection and I. cuspidata and I. latifolia showing African connection confirming the study of Yuan et al. [2]. From these phylogenies it is clearly understand that South India was colonized by two independent dispersal events i.e., once by Southeast Asian ancestor and another time by an ancestor with African affinities.

\subsection{Implications of the ITS phylogenies on infrageneric classification of Impatiens}

Impatiens is taxonomically considered as one of the most difficult genera of angiosperms, primarily due to the delicate yet hypervariable structure and fragile nature of its flowers. It is extremely difficult to examine dried specimens if prepared conventionally $[3,10]$. The first modern general treatment for the genus is the important revision of the African taxa by Grey-Wilson [10], which distinguished six informal infrageneric groups for the African species for practical diagnosis only. Based on morphological and molecular data sets, Yu et al. [12] presented a new classification of Impatiens. In which, Impatiens is divided into two subgenera, subgenus Clavicarpa and subgenus Impatiens. The subgenus Impatiens is further sub divided into seven sections such as Semeiocardium, Tuberosae, Racemosae, Impatiens, Scorpioidae, Fasciculatae and Uniflorae.

The taxonomic treatments of South Indian Impatiens of Bhaskar [5] classified South Indian species under seven sections i.e., Scapigerae, Epiphyticae, Annuae, Microsepalae, Tomentosae, Sub-Umbellatae and Racemosae. Based on the present molecular phylogenetic study, most of the species of each sections form monophyletic association with strong bootstrap support. This study confirms the morphological classifications of Bhaskar [5].

Grey-Wilson [10] observed several morphological similarities among species endemic to Africa and South India. Grey-Wilson [10] also suggested a close affinity between African and South Indian taxa and even a possible migration route connecting these two areas. Species of section Microsepalae (sub clade B1 in MP and sub clade B in BI) was included in the same sub clade of African and Madagascan species. In all the analyses, the species of section Annuae formed a separate sub clade (sub clade B2 in MP and sub clade A in BI) with strong support. All phylogenies revealed that these two sections showed sister clade relationships. These results demonstrate that species of section Microsepalae and Annuae shows African affinities. This proves the Grey-Wilson's [10] observation of morphological similarities among species endemic to Africa and South India. MP analysis (sub clade A) clearly indicates that species of sections Scapigerae, Epiphyticae, Tomentosae, Sub-Umbellatae and Racemosae showed Southeast Asian relationship. It is pointed out that these sections dispersed from Southeast Asia. This study including all representative extant sections of South India, indicates that South India was colonized from Southeast Asia by two independent dispersal events i.e., once by ancestral species of sections Scapigerae, Epiphyticae, Tomentosae, Sub-Umbellatae and Racemosae and another time by ancestral species of sections Microsepalae and Annuae, having African affinities.

\section{CONCLUSION}

The biogeographical elucidation based on this study is mainly in accordance with the conclusion of Yuan et al. [2] The 
results based on all phylogenetic analyses reveal that mainland Southeast Asia is the original place of extant Impatiens species and from where it dispersed to other places like boreal Eurasia and North America, central Asia and Eastern Europe, via the Himalayas, and to Africa and India. But our conclusion is in opposition with Jones and Smith's [9] implication of Impatiens originated in the Himalayan region, Grey-Wilson's [10] proposition of dispersal from an assumed West Gondwana origin and spread to Southeast Asia and the adjacent Sino-Himalayan region and Bhaskar's [11] suggestions of the genus Impatiens originated from Western Ghats. This study, including all the representative extant sections of South India, indicates that South India was colonized by two independent dispersal events from Southeast Asia i.e., once by ancestral species of sections Scapigerae, Epiphyticae, Tomentosae, Sub-Umbellatae and Racemosae and another time by ancestral species of sections Microsepalae and Annuae.

\section{ACKNOWLEDGEMENTS}

We thank University Grants commission (UGC), India and Kerala state Council for Science, Technology and Environment (KSCSTE), Kerala, India for supporting for instrumentation. We are also thankful to the Forest Department of Kerala, India for providing us the permission to collect samples of Impatiens species from Southern Western Ghats.

\section{Financial support and sponsorship: Nil.}

Conflict of Interests: There are no conflicts of interest.

\section{REFERENCES}

1. Janssens S, Geuten K, Yuan YM, Song Y, Kupfer P, Smets E. Phylogenetics of Impatiens and Hydrocera (Balsaminaceae) using chloroplast atpB-rbcL spacer sequences. Systematic Botany. 2006; 31(1):171-180.

2. Yuan YM, Song YI, Geuten K, Rahelivololona E, Wohlhauser S, Fischer E, Kupfer P. Phylogeny and biogeography of Balsaminaceae inferred from ITS sequences. Taxon. 2004; 53(2):391-391.

3. Grey-Wilson C. Impatiens in Papuasia, Studies in Balsaminaceae. Kew Bull. 1980a; 34: 661-688.

4. Rao R, Ayyangar K, Sampathkumar R. On the karyological characteristics of some members of Balsaminaceae. Cytologia. 1986; 51:251-260.

5. Bhaskar V. Taxonomic Monograph on Impatiens L. (Balsaminaceae) of Western Ghats, South India: The Key Genus for Endemism. Karnataka, India: Centre for Plant Taxonomic Studies; 2012.

6. Kuang RP, Duan LD, Gu JZ, Cai XZ, Cong YY, Liu KM. Impatiens liboensis sp. nov. (Balsaminaceae) from Guizhou, China. Nordic Journal of Botany. 2014; 32(4):463-467.

7. Luo $\mathrm{Q}$, Wang $\mathrm{TJ}$, Zhao LH. Impatiens shimianensis sp. nov. (Balsaminaceae) from Sichuan, China. Nordic Journal of Botany. 2015; 33(2):204-208.
8. Gogoi R, Borah S. Impatiens paramjitiana, a new species of Balsaminaceae from Arunachal Pradesh, India. Phytotaxa. 2014; 175(3):171-175.

9. Jones K, Smith J. The cytogeography of Impatiens L. (Balsaminaceae). Kew Bulletin. 1966; 20:63-72.

10. Grey-Wilson C. Impatiens of Africa, Rotterdam Balkema. Kew Bulletin. 1980b; 34:221-227.

11. Bhaskar V. The genus Impatiens L. in south India: endemism and affinities. Indian Forester. 1981; 107:368-376.

12. Yu SX, Janssens SB, Zhu XY, Lidén M, Gao TG, Wang W. Phylogeny of Impatiens (Balsaminaceae): integrating molecular and morphological evidence into a new classification. Cladistics. 2015; 1 19.

13. White TJ, Bruns T, Lee S, Taylor J. Amplification and direct sequencing of fungal ribosomal RNA genes for phylogenetics. In: Innis MA, Gelfand DH, Sninsky JJ, White TJ (ed) PCR Protocols: A Guide to Methods and Applications. Academic Press, New York. 1990; 315-322.

14. Thomson JD, Higgins DG, Gibson TJ. CLUSTALW: Improving the sensitivity of progressive multiple sequence alignment through sequence weighting, position- specific gap penalties and weight matrix choice. Nucleic Acids Research. 1994; 22:4673-4680.

15. Hall TA. BioEdit: a user-friendly biological sequence alignment editor and program for Windows 95/98/NT. In Nucleic acids symposium series. 1999; 41:95-98.

16. Swofford DL. PAUP* version 4.0b10. Phylogenetic analysis using patsimony (*and other methods), Sinauer, Sunderland, MA. 2002.

17. Darriba D, Taboada GL, Doallo R, Posada D. jModelTest 2: more models, new heuristics and parallel computing. Nature methods. 2012; 9(8):772-772.

18. Ronquist F, Teslenko M, van der Mark P, Ayres DL, Darling A. MrBayes 3.2: Efficient Bayesian Phylogenetic Inference and Model Choice across a Large Model Space. Systematic Biology. 2012; 61(3):539-42. doi:10.1093/ sysbio/sys029. 4.

19. Rambaut A. FigTree. v. 1.4. 2: tree drawing tool. 2014.

20. Janssens, SB, Knox EB, Huysmans S, Smets EF, Merckx VS. Rapid radiation of Impatiens (Balsaminaceae) during Pliocene and Pleistocene: result of a global climate change. Molecular Phylogenetics and Evolution. 2009; 52(3), 806-824.

How to cite this article:

Shajitha PP, Dhanesh NR, Ebin PJ, Joseph L, Devassy A, John R, Augustine J, Mathew L. Molecular Phylogeny of Balsams (Genus Impatiens) Based on ITS Regions of Nuclear Ribosomal DNA Implies Two Colonization Events in South India. J App Biol Biotech. 2016; 4 (06): 001-009. DOI: 10.7324/JABB.2016.40601 